\title{
Editorial: New Developments in International Business and Economics in CEECs
}

The political and economic shift of early 1990s in Central and Eastern Europe countries (CEECS) initiated a fundamental process of transformation of the region's economies and firms (Galgóczi, 2002). The formerly regulated economies gradually became an integral part of the global economy (Dayan \& Gorynia, 2009; Szarucki, 2013). While the unprecedented scale of change provided then a unique research setting for international business and economics scholars, there have been recent discussions about the extent to which the CEE region is still a specific business environment (Schuh \& Rossmann, 2010).

In fact, there is still a significant level of heterogeneity from both macro- and microeconomic perspectives, which raises research questions. First, in what ways do CEEbased firms become internationalized and what are the determinants of their international competitiveness? Second, can CEE-based businesses accelerate the catchup process by drawing on the experience of their counterparts in advanced economies? The answers to these questions were sought at two international conferences based in the CEE region: "Competitiveness of the CEE Region in the Global Economy", the annual meeting of the CEE Chapter of the Academy of International Business (AIB-CEE) held in Budapest on 9-11.10.2014, and the International Scientific Conference "Contemporary Issues in Business, Management and Education '2014" held in Vilnius on 13-14.11.2014. The present issue of Entrepreneurial Economics and Business Review presents selected papers from both conferences, which relate to important research problems and touch upon crucial areas of business and management. Accordingly, the issue of EBER consists of two parts. The first one contains three papers devoted to both active and passive internationalisation in the CEE region, in particular, the international strategies of CEEbased firms and transformation of the business environment through privatisation, which remains a characteristic feature of the region. The second part with further three papers, presents contributions related to improving managerial decisions related to financial investments and contract designs.

The first paper, Export performance clusters of the Hungarian enterprises - What factors are behind the successful export activities?, written by Annamaria Kazai Ónodi (Corvinus University of Budapest, Hungary), provides in-depth insights into the salient features of Hungarian exporters between 1999 and 2013. The author performs cluster analysis in order to identify how exporters can be grouped according to their export performance. The results indicate that the most successful export-oriented companies produced more than $60 \%$ of export revenue and had the highest export intensity, as well as above-average profitability. The study moreover suggests that a lower price is a less important success factor than quality, relationships, or fast and flexible delivery. The 
second paper, Winning in Europe - International Strategies for Hungarian Professional Sports Clubs, prepared by Miklos Kozma and Krisztina András (Corvinus University of Budapest, Hungary), aims at identifying key patterns in the international strategies of Hungarian professional sports clubs. The global competition challenges which the Hungarian professional sports clubs face are expected to stimulate the development of specific strategic patterns which may extend internationalisation models developed in advanced economies. The third paper, Analysis of Large-Scale Privatisation in the Czech Republic in the Years 1991-2005 and Its Basic Assessment, by Karel Havlíček, Ivana Turková, Gabriela Dlasková (University of Finance and Administration, Czech Republic) aims to analyse and evaluate different methods of Czechoslovak and Czech privatisation in the years 1991-2005. The study suggests that while the best results were reported by companies sold directly to foreign investors, voucher privatisation and direct sales to specific domestic investors can also be regarded as well performing.

The article entitled Risk factors in derivatives markets and authored by Raimonda Martinkute-Kauliene (Vilnius Gediminas Technical University, Lithuania) seeks to analyse and present a classification of risks inherent to derivative securities. The paper suggests that derivative contracts are as risky as every financial activity in the market, their market, liquidity, credit, counterparty, legal and transactions risks being the most relevant. The fifth paper, Real Time Investments with Adequate Portfolio Theory by Alina Kvietkauskienè (Vilnius Gediminas Technical University, Lithuania) attempts at formulating an investment decision making scheme using the adequate portfolio model. The study implies that adequate portfolio model is more suitable for investment when stocks in portfolio are from different sectors. The German market has been identified as the most stable and one of the most suitable markets for investors. The final article of this issue, Knowledge Management in Composition of Construction Contracts by Eva Trinkūnienè and Vaidotas Trinkūnas (Vilnius Gediminas Technical University, Lithuania), proposes a model which allows managing information in construction contracts composition. The model can be used and implemented in the evaluation system of construction contracts to avoid mistakes and employ best practices in construction contract making.

\section{Łukasz Puślecki, Piotr Trąpczyński Guest Editors}

\section{REFERENCES}

Dayan, L., \& Gorynia, M. (2009). Modes, rythmes et perspectives d'internationalisation de l'économie et des entreprises polonaises. Mondes en Développement, 37(145), 109-126.

Galgóczi, B. (2002). Los costes sociales de la transformación en Europa Central y Oriental. Papeles del Este, 4, 1-14.

Schuh, A., \& Rossmann, A. (2010). Schwerpunkte und Trends in der betriebswirtschaftlichen Mittelund Osteuropaforschung: Ein Literaturüberblick zum Zeitraum 1990-2005. In R. Moser (Ed.), Internationale Unternehmensführung. Entscheidungsfelder und politische Aspekte (pp. 161204), Wiesbaden: Gabler.

Szarucki, M. (2013). Editorial: Modern Challenges for Business and Economy in CEE Countries. Entrepreneurial Business and Economics Review, 1(4), 5-6. 